\title{
Modeling of Thermal Mass in a Small Commercial Building and Potential Improvement by Applying TABS
}

\author{
Peizheng $\mathrm{Ma}^{1, *}$, Nianhua Guo ${ }^{2}$ \\ ${ }^{1}$ Department of Mechanical Engineering, Stony Brook University, Stony Brook, United States \\ ${ }^{2}$ Department of Asian and Asian American Studies, Stony Brook University, Stony Brook, United States \\ *Corresponding author: peizheng.ma@alumni.stonybrook.edu
}

Received February 15, 2015; Revised March 25, 2015; Accepted April 21, 2015

\begin{abstract}
With a resistor-capacitor model built in Matlab/Simulink, the role of envelope/interior thermal mass (eTM/iTM) in a small commercial building is investigated systematically. It concludes that light-weight concrete is a little worse than normal-weight concrete but much better than wood as eTM or iTM for controlling operative temperature variation in the building. In order to combine the advantages of radiant cooling/heating with the heat storage of massive building structure, an attractive technique called TABS (thermally activated building systems) is applied to the building to investigate the potential improvement. Simulations demonstrate that TABS can keep the operative temperature level around the comfort zone with small variations. As TABS is a low-temperature heating and high-temperature cooling technique, it suggests that natural energy gradient driven low-power equipment, such as cooling tower and rooftop solar thermal panels, can be used to achieve free cooling/heating combining photovoltaics.
\end{abstract}

Keywords: building energy modeling, $R C$ model, thermal mass, TABS, small commercial building, heat transfer and storage

Cite This Article: Peizheng Ma, and Nianhua Guo, "Modeling of Thermal Mass in a Small Commercial Building and Potential Improvement by Applying TABS." American Journal of Mechanical Engineering vol. 3, no. 2 (2015): 55-62. doi: 10.12691/ajme-3-2-4.

\section{Introduction}

Thermal mass [1] "has the ability to absorb and store heat energy during a warm period of heating and to release heat energy during a cool period later." Building thermal mass can be classified as exterior (envelope) thermal mass (eTM) and interior thermal mass (iTM) based on its location and function. Thermal mass is a powerful tool for controlling indoor temperature for thermal comfort. The green building engineer M. Schuler [2] noted, "Many of us have experienced that moment during a warmer summer day, upon entering an old church. One step into the space and the climate changes totally...allows us to feel a temperature even below the air temperature”. Most of us have the same intuitive appreciation of thermal mass in making a building thermally comfortable. There is a large number of architectural and/or engineering publications on the use of thermal mass in building applications [3-14].

By analytical and numerical methods, two papers investigated the dynamic heat transfer performance of interior and exterior planar thermal mass $[1,15]$ subject to sinusoidal heating and cooling. In these two papers, the indoor air temperature acted as an input function rather than an output result, which made it hard to predict the effect of thermal mass on the indoor air temperature. The resistor-capacitor (RC) model, which can solve the problem and was validated widely [16-25], will be used to systematically investigate the role of thermal mass in a small commercial building in this paper. Unlike residential buildings that are envelope (externally) load dominated type, commercial buildings are usually internally load dominated type, which uses the majority of energy for internal needs (such as lights, computers, equipment, etc.) leading to large internal heat generation [26].

This paper is organized as follows: the details of the small commercial building will be given in Section 2; Section 3 will present the modeling of the building in Matlab/Simulink, and the role of thermal mass in the building will be investigated in Section 4 using the built model; Section 5 will explore the potential improvement by applying TABS (thermally activated building systems) in the building; and the paper will be closed with main conclusions in Section 6.

\section{Schematics of the Building}

\subsection{The Small Commercial Building}

The small commercial building, which is called the Suffolk County Health Center [27], also known as the Farmingville Health Center, is a one-story south-facing building located in Farmingville, Long Island, New York, United States. Its usages include environmental health, alcoholism and substance abuse, mental health, children's 
clinic, public health, and so on. The dimension of the health center is about $47.24 \mathrm{~m} \times 30.48 \mathrm{~m} \times 3.96 \mathrm{~m}$. So the total area and volume are about $1440 \mathrm{~m}^{2}$ and $5700 \mathrm{~m}^{3}$, respectively. A picture of the health center is shown in Figure 1 and the floor plan is shown in Figure 2.

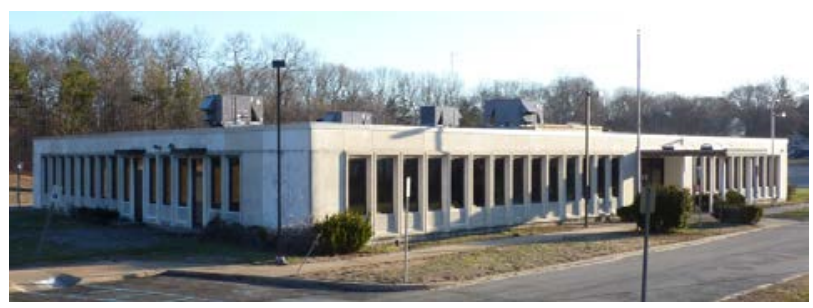

Figure 1. A picture of the Suffolk County Health Center

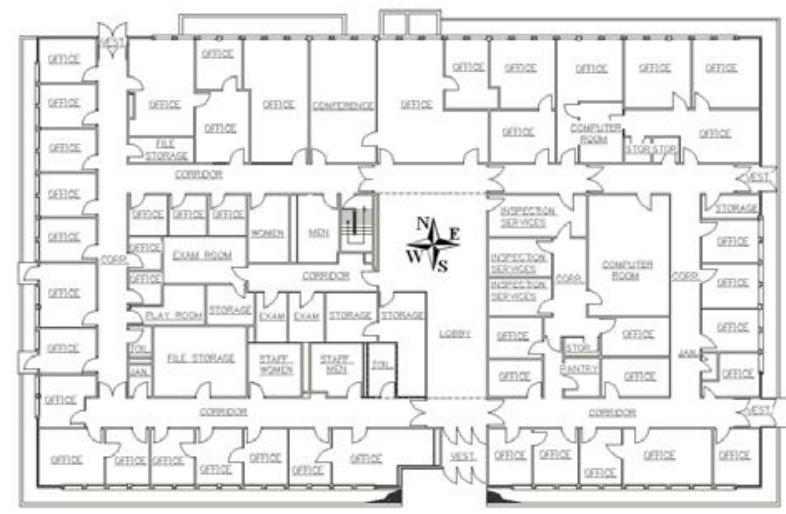

Figure 2. Floor plan of the Suffolk County Health Center

There are four exterior entrance doorways, all of which are made of aluminum and glass. In the middle of the south wall, there is a main entrance, which has three doors with a vestibule and three solid wood doors to the interior. Over the main entrance, there is a $2.800 \mathrm{~m}$ long overhang. The other three of the entrance ways have double doors with a vestibule and solid wood double doors to the interior. The health center has 71 identical $0.965 \mathrm{~m} \times$ $1.829 \mathrm{~m}$ high efficiency windows, where 7, 24, 14 and 26 are east-, south-, west- and north-facing, respectively. The exterior walls surrounding the main entrance are made of light colored, precast concrete and marble. The rest of the exterior walls are light in color and made of precast concrete. All of the walls use foam insulation. The health center has an upper level roof and a lower level roof. The height difference of the two roofs is $0.152 \mathrm{~m}$. The ceiling heights under the upper and lower roofs are $2.438 \mathrm{~m}$ and $2.591 \mathrm{~m}$, respectively. The dimension of the upper level roof is $13.818 \mathrm{~m} \times 7.620 \mathrm{~m}$, which is only about $7 \%$ of the total roof area.

Inside of the health center, there exist 36 staff offices, a small file storage area, a large conference room, a computer room, three small storage areas and a very small janitor's closet along the perimeter of the building. There is a big reception/waiting lobby near the center of the building. On the east of the lobby, there contains four offices, three inspection services rooms, a large computer room, a small storage room and a pantry. The section on the west of the lobby is a little bigger than the east one. It contains five offices, three examination rooms, a children's play room, three storage rooms, one large file storage room, a janitor's closet and six restrooms. It is also the location of the only staircase (to the186 m2 semiconditioned basement) in the building.
There are 57 Suffolk County employees in the health center during regular working hours and the designed occupancy capacity is 155 persons (assumed $9.290 \mathrm{~m}^{2}$ per person). The health center opens from 9:00 AM to 9:00 PM on Monday-Thursday and 9:00 AM to 5:00 PM on Fridays.

\subsection{Thermal Resistance of the Envelope}

The thermal resistance of the building envelope contains two parts: the building material resistances and the surface air film resistances. Building materials also have heat capacities, which are modeled as capacitors. The thermal network of the building envelope is in Figure 3.

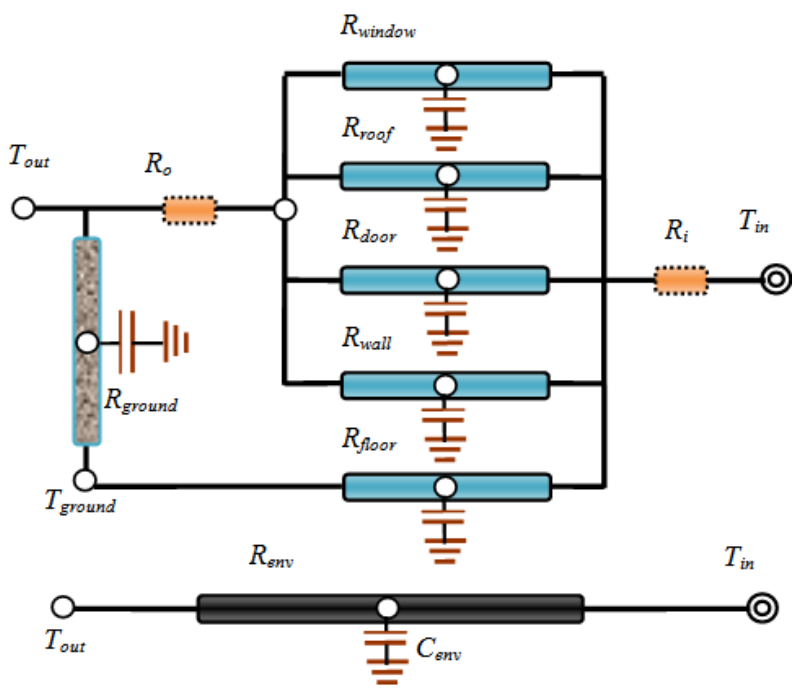

Figure 3. Thermal network of the building envelope

The thermal resistances of the building envelope can be calculated as follows.

Windows: All of the 71 windows of the health center are "double-glazed, anodized, aluminum thermal break frame". From Table 5-16 in [28], the thermal resistance is $0.345 \mathrm{~m}^{2} \mathrm{~K} / \mathrm{W}$. As the total area of the windows is 125.46 $\mathrm{m}^{2}$, the total thermal resistance due to the windows is: $R_{\text {window }}=0.002750 \mathrm{~K} / \mathrm{W}$.

Roofs: The structure of the upper lower level roof roofs is the same: new roof membrane, adhesive, new $0.038 \mathrm{~m}$ thickness insulation, existing built-up roofing, existing insulation and roof deck (both of the insulation and deck are $0.038 \mathrm{~m}$; the deck was filled with lightweight concrete). The thermal resistance of the roof materials is $1.980 \mathrm{~m}^{2} \mathrm{~K} / \mathrm{W}$. As the total area of the roofs is $1440 \mathrm{~m}^{2}$, the total thermal resistance due to the roofs is: $R_{\text {roof }}=$ $0.001375 \mathrm{~K} / \mathrm{W}$.

Doors: For the four entrances, there are nine operable swing doors made of aluminum and glass. The thermal resistance of this kind of door is $0.143 \mathrm{~m}^{2} \mathrm{~K} / \mathrm{W}$. [28] Behind the glass doors, the thermal resistance due to the indoor air film is $0.141 \mathrm{~m}^{2} \mathrm{~K} / \mathrm{W}$ calculated from Chapter 15 in [29]. Beyond the vestibules, there are nine solid wood doors, whose thermal resistance is $0.383 \mathrm{~m}^{2} \mathrm{~K} / \mathrm{W}$. [28] On the wood door surfaces, the thermal resistance due to the air film is $0.121 \mathrm{~m}^{2} \mathrm{~K} / \mathrm{W}$. [29] The dimension of the doors is $0.914 \mathrm{~m} \times 2.134 \mathrm{~m}$ and thus the total area of the doors is $17.56 \mathrm{~m}^{2}$. Therefore, the total thermal resistance due to the doors is: $R_{\text {door }}=0.044875 \mathrm{~K} / \mathrm{W}$.

Exterior walls: Most of the exterior walls were constructed with $0.076 \mathrm{~m}$ thick precast concrete panels, 
insulated with foam and finished with plaster. The thermal resistance due to the wall materials is about $2.200 \mathrm{~m}^{2} \mathrm{~K} / \mathrm{W}$. The walls adjacent to the main entrance were constructed with concrete and marble block, whose thermal resistance is a little higher. As the area is much smaller, the difference can be neglected. After subtracting the area of windows and doors, the total area of the walls is 472.93 $\mathrm{m}^{2}$. Therefore, the total thermal resistance due to the walls is: $R_{\text {wall }}=0.004652 \mathrm{~K} / \mathrm{W}$.

Floor: The health center has a slab-on-ground floor, which was constructed with $0.102 \mathrm{~m}$ normal-weight concrete slabs directly on the ground. The bottom of the basement has a $0.051 \mathrm{~m}$ concrete slab. The wall below grade is $0.305 \mathrm{~m}$ concrete and has a $0.051 \mathrm{~m}$ insulated pane. The estimated thermal resistance for the belowgrade wall is $2.997 \mathrm{~m}^{2} \mathrm{~K} / \mathrm{W}$, which is much higher than that of other parts of the envelope. Since the weather condition is moderate and the temperature of the ground is much stable than that of the outdoor air, "for floors in direct contact with the ground, or over an underground basement that is neither ventilated nor conditioned, heat transfer may be neglected for cooling load estimates", as said in Chapter 7 of [28]. Therefore, the floor and ground resistance is treated as infinitely large.

Air films: The thermal resistances of the indoor and outdoor air films are 0.141 and $0.037 \mathrm{~m}^{2} \mathrm{~K} / \mathrm{W}$, respectively. Therefore, the total thermal resistances due to the indoor and outdoor air films are $R_{i}=0.000040 \mathrm{~K} / \mathrm{W}$ and $R_{o}=0.000018 \mathrm{~K} / \mathrm{W}$, respectively.

\subsection{Thermal Resistance Of Infiltration And Ventilation}

There are two classifications of air exchange between outdoor air and indoor air [28]: infiltration/exfiltration and ventilation. The difference of the two patterns is that, in the former one, the air flow through cracks and other openings is unintentional and uncontrolled by human, and in the latter one, the outdoor air is intentional introduction into a building. According to the condition of the health center, the thermal resistance is $0.992 \mathrm{~m}^{2} \mathrm{~K} / \mathrm{W}$ for infiltration and up to $0.594 \mathrm{~m}^{2} \mathrm{~K} / \mathrm{W}$ for infiltration and ventilation. The value of $0.667 \mathrm{~m}^{2} \mathrm{~K} / \mathrm{W}$ is selected in the simulation, and the total thermal resistance due to the infiltration and ventilation is $R_{v i}=0.000463 \mathrm{~K} / \mathrm{W}$, which is parallel to the building envelope thermal resistance.

\subsection{Radiation Solar Energy Input Through Windows}

One important part of building energy gains is the radiation solar energy input through windows. Using the method given in [30], a program is written in Matlab to calculate the solar irradiance, which is the solar intensity that is incident perpendicular (normal) to one unit area of the plane surface. The total solar irradiance incident upon a flat surface, $I_{T}\left[\mathrm{~W} / \mathrm{m}^{2}\right]$, includes the direct beam component, the diffuse component and the reflected component.

As the window type is double glazing with low-e coating, the shading coefficient, $C_{s c}$, is $0.32 \sim 0.60$ and choose 0.46 . In most commercial buildings, besides using glazing, shading strategies are also used to control solar heat gain to minimize cooling requirements. In Chapter 15 of [29], many details about shading are given. It mentions that outdoor shading devices reduce solar heat gain more effectively than indoor devices, but indoor devices are easier to operate and adjust. It also points out that "fenestration products fully shaded from the outside reduce solar heat gain by as much as $80 \%$ ". Assume that $20 \%$ solar energy can go into the building and this gives a coefficient $C_{s d}=0.20$. Therefore, on clear days (i.e., sunny and cloudless), the heat flux of solar energy gain, $q_{s}$ $\left[\mathrm{W} / \mathrm{m}^{2}\right]$, can be obtained as

$$
q_{s}^{\prime \prime}=C_{s d} C_{s c}\left(I_{b}+I_{d}+I_{f}\right)
$$

Solar energy input through windows of the health center is shown in Figure 4.

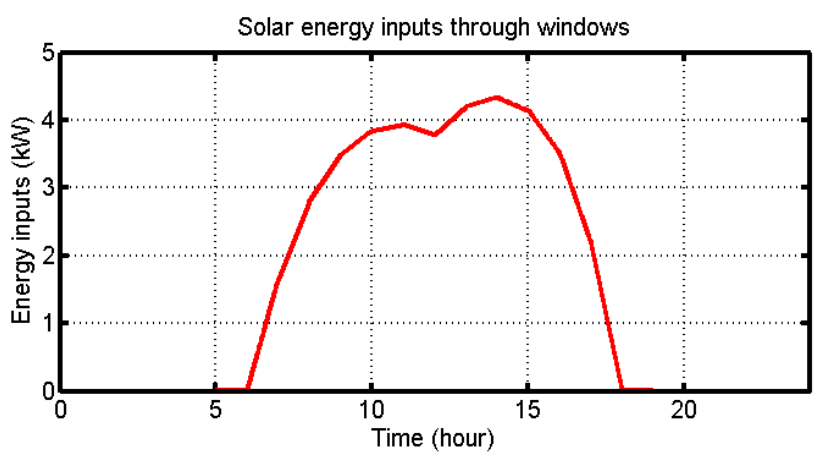

Figure 4. Solar energy inputs through windows of the health center

\subsection{Internal Heat Gains}

The internal heat gains, which are the heat energy emitted by occupants, lighting and equipment, contribute a significant amount of heat to the total sensible and latent heat gains in a commercial building.

According to Table 1 in Chapter 18 of [29], the heat gain, including sensible and latent, from occupants is about 130 watts per person. The energy gains due to lighting and equipment are 0.75 and $1.00 \mathrm{~W} / \mathrm{ft}^{2}$, respectively. The hour-by-hour internal heat gains on typical workdays are shown in Figure 5.

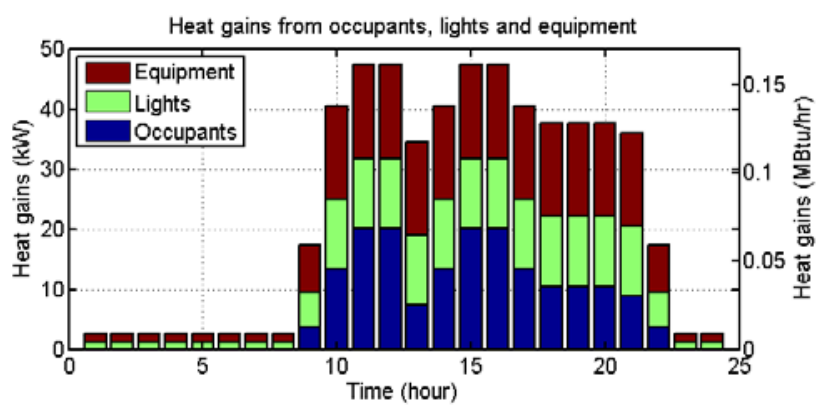

Figure 5. Internal heat gains of the health center

Comparing with Figure 4, it is clear that the internal heat gains are about ten times more than the solar energy input through windows. This is why commercial and office buildings are called internally load dominated buildings. For this kind of buildings, cooling is a dominate concern. In contrast, for the so called envelope (externally) load dominated building (typical residential buildings), the heating requirement is often at least as important as cooling and in many cases (in cold climate) much more important. 


\subsection{Interior Thermal Mass}

The iTM in the health center can be divided into thermal mass due to internal walls/doors and thermal mass due to office furniture. The main material composition of the internal walls in the health center is "one layer of $5 / 8$ " gypsum wallboard on both sides". As the thermal-physical properties of gypsum board are similar to that of wood, [1] after ignoring the air and studs between the two gypsum wallboards, the internal walls can be treated as $0.032 \mathrm{~m}$ wood boards. From Figure 2, the length of all the interior walls is about $550 \mathrm{~m}$. Since the height of the interior walls is about $2.44 \mathrm{~m}$, the total area of the internal wall surface (two sides) is $2682 \mathrm{~m}^{2}$ and the volume is about $42.6 \mathrm{~m}^{3}$. All the 100 internal doors are modeled as two $0.013 \mathrm{~m}$ wood layers separated by a $0.013 \mathrm{~m}$ air space with a 0.914 $\mathrm{m} \times 2.134 \mathrm{~m}$ dimension. So the total area of the internal door surface (two sides) is $390 \mathrm{~m}^{2}$ and the volume is about $5.0 \mathrm{~m}^{3}$. All the furniture is assumed to be composed of $0.025 \mathrm{~m}$ wood layers and the area is equal to the floor area. Thus the total area (two sides) and volume of the furniture are about $2880 \mathrm{~m}^{2}$ and $36.6 \mathrm{~m}^{3}$, respectively.

Therefore, the total area (two sides) and volume of all the iTM are about $5952 \mathrm{~m}^{2}$ and $84.2 \mathrm{~m}^{3}$, respectively. And thus the average thickness of the iTM in the health center is about $0.028 \mathrm{~m}$.

\section{Building Modeling In Matlab/Simulink}

In this paper, the health center is modeled by the RC method in Matlab/Simulink as shown in Figure 6. In the figure, the units of the symbols are: $C(\mathrm{~J} / \mathrm{K})$; $\mathrm{T}\left(\mathrm{K}\right.$ or $\left.{ }^{\circ} \mathrm{C}\right)$; $R(\mathrm{~K} / \mathrm{W})$; and $q(\mathrm{~W}=\mathrm{J} / \mathrm{s})$. This model has elements of the building envelope, the solar energy input, the internal heat gains, the iTM, the indoor air, and the outdoor air. Most of them were described in Section 2. The indoor air temperature, $T_{\text {in }}\left(\mathrm{K}\right.$ or ${ }^{\circ} \mathrm{C}$ ) is allowed to "float". September 15 is selected for the calculation. The average high and low temperatures of the outdoor air in this month [31] are $14^{\circ} \mathrm{C}$ and $23^{\circ} \mathrm{C}$, respectively. The outdoor air temperature,

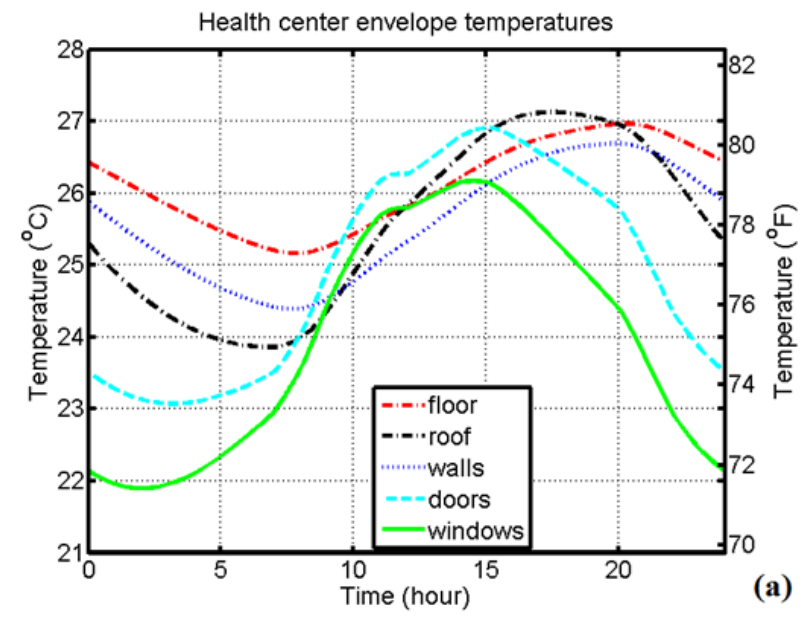

$T_{\text {out }}\left(\mathrm{K}\right.$ or ${ }^{\circ} \mathrm{C}$ ) is supposed as a sinusoidal function with a period of 24 hours. The time step of the simulation is $10 \mathrm{~s}$.

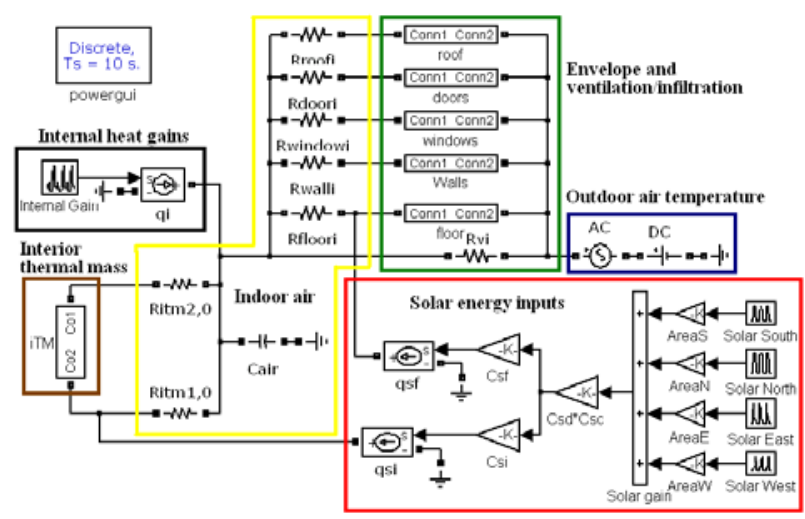

Figure 6. RC model of the health center in Matlab/Simulink

For the sake of simplicity for simulation, except the windows, the health center envelope in the model is made of four materials: wood (with low thermal conductivity and small volumetric heat capacity), normal-weight concrete (with high thermal conductivity and large volumetric heat capacity), light-weight concrete (with moderate thermal conductivity and moderate volumetric heat capacity), and insulation (with very low thermal conductivity and almost no heat capacity). The roofs, the exterior walls and the floor are insulated by the insulation from outside. Main properties of the materials are listed in Table 1.

\begin{tabular}{|c|c|c|c|c|}
\hline \multicolumn{2}{|c|}{ Table 1. Specifications of building materials } \\
\cline { 2 - 5 } & Conductivity & Density & $\begin{array}{c}\text { Mass specific } \\
\text { heat }\end{array}$ & $\begin{array}{c}\text { Volumetric } \\
\text { specific heat }\end{array}$ \\
\hline Wood & 0.12 & 510 & 1.382 & 704.8 \\
\hline $\begin{array}{c}\text { NW } \\
\text { concrete }\end{array}$ & 1.90 & 2320 & 0.795 & 1844.4 \\
\hline $\begin{array}{c}\text { LW } \\
\text { concrete }\end{array}$ & 0.61 & 1600 & 0.921 & 1473.6 \\
\hline Insulation & 0.04 & 0 & 0.000 & 0.0 \\
\hline
\end{tabular}

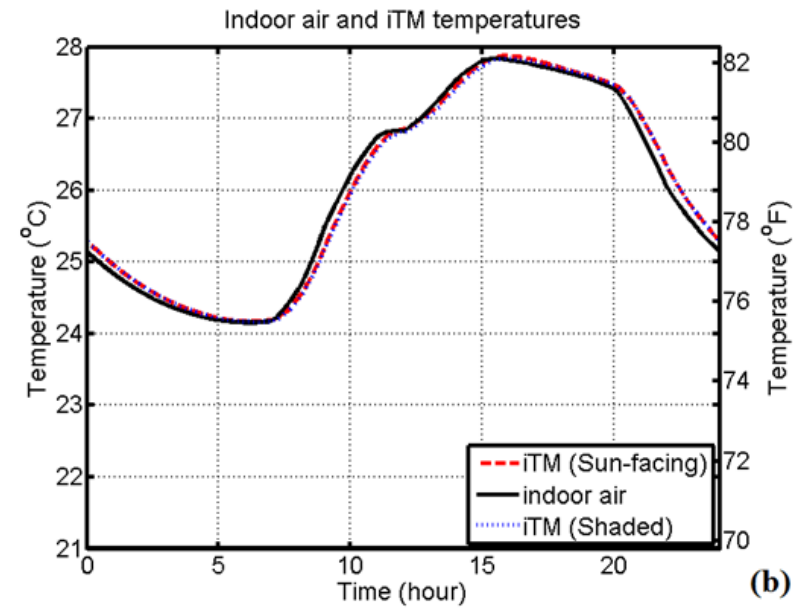

(b)

Figure 7. Simulation results of the health center

Simulation results are shown in Figure 7. In the simulation, the heat capacities of the building elements are: roofs $0.81 \times 10^{8} \mathrm{~J} / \mathrm{K}$; exterior walls $0.66 \times 10^{8} \mathrm{~J} / \mathrm{K}$; floor $2.70 \times 10^{8} \mathrm{~J} / \mathrm{K}$; iTM $0.59 \times 10^{8} \mathrm{~J} / \mathrm{K}$; and indoor air $0.07 \times$ $10^{8} \mathrm{~J} / \mathrm{K}$ (can be neglected). The heat capacities of windows and doors are neglected.
In Figure 7 (a), it is clear that because of higher thermal resistance values, the mean temperatures of the windows, the doors, the roofs, the exterior walls and the floor increase stepwise, and the temperature variations of them decrease stepwise. The temperature peaks of the windows and the doors are at 3:00 PM, which coincide with the 
peak of the internal heat gains. The temperature peak of the roofs lags several hours due to its large heat capacity. The temperature peaks of exterior walls and the floor even lag to the evening because of their large heat capacity and high thermal conductivity.

In Figure 7 (b), the temperatures of the indoor air and the iTM almost coincide, because the iTM thickness is small and the solar energy input is much smaller than the internal heat gains. The indoor air temperature variation is about $3.68{ }^{\circ} \mathrm{C}$, which may cause thermal discomfort for occupants in the health center.

Combining all the temperatures in the health center, the operative temperature is in Figure 8. Operative temperature is the "uniform temperature of a radiantly black enclosure in which an occupant exchanges the same amount of heat by radiation plus convection as in the actual nonuniform environment”. [28] Operative temperature is one of the most important parameter in the comfort zone chart specified in the ANSI/ASHRAE Standard 55. In Figure 8, the operative temperature varies between $24.23{ }^{\circ} \mathrm{C}$ and $27.60{ }^{\circ} \mathrm{C}$. According to [32], in summer, the comfort range of operative temperature is $24.5^{\circ} \mathrm{C} \sim 26.0{ }^{\circ} \mathrm{C}$ for a maximum $6 \%$ dissatisfied permissible rate and is $23.5^{\circ} \mathrm{C}$ $\sim 27.0{ }^{\circ} \mathrm{C}$ for a maximum $10 \%$ dissatisfied permissible rate. Therefore, the $3.37^{\circ} \mathrm{C}$ variation is corresponding to nearly $10 \%$ dissatisfied permissible rate.

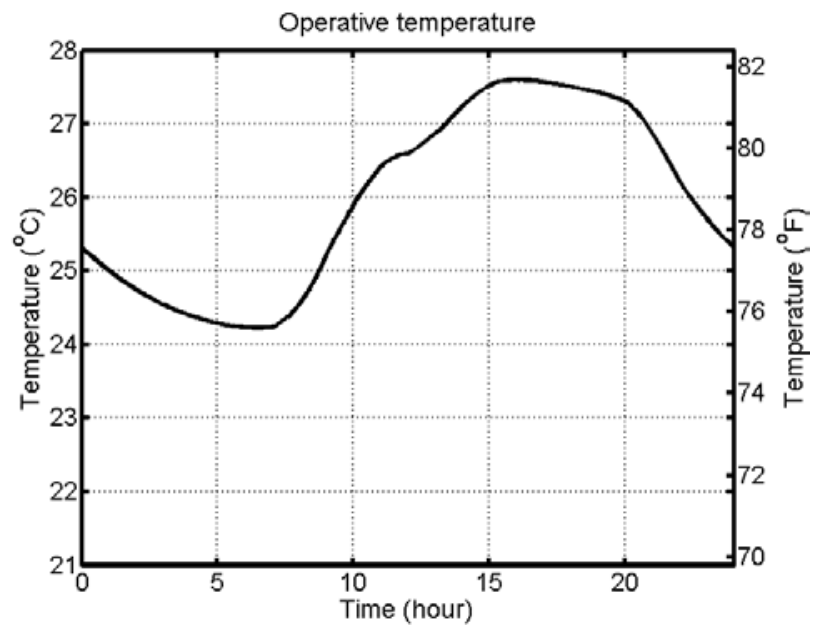

Figure 8. Operative temperature of the health center in September

\section{Thermal Mass in the Health Center}

Although the thermal mass in the health center practically cannot be varied much, we can investigate the role of thermal mass easily with the model developed in the previous section. Some cases in this section may be not realistic in buildings and are only for reference purpose.

\subsection{Exterior Thermal Mass}

For the health center, the eTM is mainly from the 0.038 $\mathrm{m}$ lightweight concrete filled in the roof, the $0.076 \mathrm{~m}$ precast concrete panels in the exterior walls, and the 0.102 $\mathrm{m}$ normal-weight concrete slabs in the floor. Now let us replace all the concrete to normal-weight concrete, lightweight concrete or wood and vary their thickness. Meanwhile, the corresponding thermal resistances will be kept the same as the original ones by changing the thickness of the insulation. Simulation results are shown in Table 2. In the table, except the extreme case in the first column, the thickness is doubled from $0.025 \mathrm{~m}$ to $0.400 \mathrm{~m}$. Cells are colored in green when the operative temperature variation is smaller than $2{ }^{\circ} \mathrm{C}$; buildings are considered with good thermal comfort in this region. When the variation is bigger than $4{ }^{\circ} \mathrm{C}$, cells are colored in red; such big variations are not accepted for occupants and extra heating or cooling is needed. Between them, cells are colored in yellow; people can accept the variation range, but buildings are not considered to be thermally comfortable.

In Table 2, the operative temperature variation can be up to $12.57{ }^{\circ} \mathrm{C}$ in the extreme case with no eTM. When the amount of the eTM is small, the variation is large and in the red zone. However, when the concrete thickness is a little bigger, the variation reaches the yellow zone. By contrast, no matter how thick the wood eTM is, the variation is still in the red zone. There is no values in the last two cells, because when the wood thickness is 0.400 $\mathrm{m}$, the insulation thickness becomes negative in the simulation. Unfortunately, there is no variation entering the green zone.

From Table 2, we can conclude that as eTM for controlling the operative temperature variation, normalweight concrete is the best, wood is the worst and lightweight concrete is in between.

Table 2. Operative temperature variations when changing the eTM thickness

\begin{tabular}{|c|c|c|c|c|c|c|}
\hline \begin{tabular}{|c|} 
\\
$\Delta T_{o p}(\mathrm{~K})$ \\
material
\end{tabular} & 0.000 & 0.025 & 0.050 & 0.100 & 0.200 & 0.400 \\
\hline NW concrete & 12.57 & 5.06 & 3.40 & 2.62 & 2.52 & 2.64 \\
\hline LW concrete & 12.57 & 5.76 & 3.96 & 3.19 & 3.27 & 3.32 \\
\hline Wood & 12.57 & 8.23 & 6.35 & 5.64 & 5.56 & \\
\hline
\end{tabular}

\subsection{Interior Thermal Mass}

Table 3. Comparison of concrete and wood as iTM

\begin{tabular}{|c|c|c|c|c|c|c|}
\hline & \multicolumn{6}{|c|}{ Normal-weight concrete } \\
\hline \begin{tabular}{|c|} 
\\
$\Delta T_{o p}(\mathrm{~K})$ \\
area $\left(\mathrm{m}^{2}\right)$
\end{tabular} & 0.000 & 0.025 & 0.050 & 0.100 & 0.200 & 0.400 \\
\hline 1488 & & 15.66 & 10.68 & 7.16 & 5.69 & 5.64 \\
\hline 2976 & 22.76 & 11.07 & 6.65 & 4.10 & 3.13 & 3.08 \\
\hline 5952 & & 6.82 & 3.78 & 2.17 & 1.60 & 1.56 \\
\hline & \multicolumn{6}{|c|}{ Light-weight concrete } \\
\hline \begin{tabular}{|c|} 
\\
$\Delta T_{o p}(\mathrm{~K})$ \\
area $\left(\mathrm{m}^{2}\right)$ \\
\end{tabular} & 0.000 & 0.025 & 0.050 & 0.100 & 0.200 & 0.400 \\
\hline 1488 & & 17.13 & 12.21 & 8.26 & 6.83 & 7.25 \\
\hline 2976 & 22.76 & 12.74 & 7.88 & 4.88 & 3.91 & 4.21 \\
\hline 5952 & & 8.16 & 4.59 & 2.64 & 2.07 & 2.25 \\
\hline & \multicolumn{6}{|c|}{ Wood } \\
\hline \begin{tabular}{|c|} 
\\
$\Delta T_{o p}(\mathrm{~K})$ \\
area $\left(\mathrm{m}^{2}\right)$ \\
\end{tabular} & 0.000 & 0.025 & 0.050 & 0.100 & 0.200 & 0.400 \\
\hline 1488 & & 20.41 & 17.11 & 12.64 & 11.40 & 11.94 \\
\hline 2976 & 22.76 & 17.84 & 12.85 & 8.47 & 7.55 & 8.07 \\
\hline 5952 & & 13.45 & 8.33 & 5.03 & 4.47 & 4.87 \\
\hline
\end{tabular}

Now let us investigate the role of the iTM in the health center. In order to show the iTM effect more clearly, the health center envelope is assumed to be built by insulation only, i.e., the heat capacities of the envelope is assumed to 
be zero. Originally, the iTM in the health center is considered as $0.028 \mathrm{~m}$ thick wood with a total area of $5952 \mathrm{~m}^{2}$ (two sides). In this section, besides wood, the materials will be replaced to normal-weight concrete or light-weight concrete, the thickness will be varied from 0 to $0.400 \mathrm{~m}$, the area (two sides) will be changed from $1488 \mathrm{~m}^{2}$ to $5952 \mathrm{~m}^{2}$. Simulation results are listed in Table 3. The cells are colored following the rules in Table 2 .

From Table 3, we can find: for wood iTM, all of the cells are in red, which means that wood is really a bad iTM for controlling the operative temperature variation; for normal-weight concrete iTM, although most of the calls are in red, the variation can enter the yellow and green zones if the iTM amount and the thickness are big enough; for light-weight concrete iTM, the variation can only reach the yellow zone. In summary, light-weight concrete is a little worse than normal-weight concrete but much better than wood as iTM.

\section{Potential Improvement By Using TABS}

The calculations in Section 4 shows that a great amount of building thermal mass is necessary for controlling the operative temperature variations in a small range. However, besides the temperature range, we are also concern with the temperature level when considering the thermal comfort of a building. Until now, all simulations are under the assumption that the ambient temperature is neither too high nor too low. Therefore, the operative temperatures float around the comfort zone. However, beyond this assumption, extra heating or cooling is needed to control the temperature level.

One attractive technique is the so-called TABS (thermally activated building systems), which "combines the advantages of radiant cooling [and/or heating] with the thermal storage of massive concrete ceilings [and/or floors]" [33]. In this section, TABS will be applied to the health center and the potential improvement under the cooling and heating conditions will be investigated.

\subsection{Brief Background Of TABS}

The practice of thermally activating building mass was originally established by a Swiss engineer, Robert Meierhans, who published two important papers [33,34] in the 1990s. Later it is known as thermally activated building systems (TABS). The TABS movement has since gathered great momentum in Europe, especially in Switzerland and Germany. In recent two decades, many researches on TABS were published [18,21,22,23,32,35-40]. TABS is "a most attractive strain of radiant cooling," [23] but it is still not well known out of Europe, including the North America [41]. This paper aims to take a small step towards the success of TABS in the whole world.

The key innovation of TABS is the replacement of the old air-based paradigm with the water-based paradigm. Water is 832 times denser than air; a $1 \mathrm{~cm}$ water pipe delivers the same amount of heat as an $18 \mathrm{~cm}$ air duct and is much easier to install in small spaces. Compared with air, water is a more space-efficient method of transferring heat and coldness around a building, as well as a more energy-efficient method: heat loss from air ducts is eliminated; air infiltration energy loss is reduced; the effective use of building elements as thermal mass; and so on.

In TABS, water carrying pipes are embedded in building structure (concrete slabs of roofs, floors or walls). The whole slab (with its large thermal mass) is activated because of the water pipes placed in the slabs. As a result, a building's operative temperature remains within thermal comfort zone in the daytime, and in the nighttime the water can be cooled by the cold ambient air using a cooling tower or off-peak power using a chiller.

Notice that TABS does not sacrifice thermal comfort of the buildings. In fact, this new kind of thermal environment is more comfortable as pointed out by Alexander et al. in A Pattern Language [42]: "It turns out that people are more comfortable when they receive radiant heat at a slightly higher temperature of the air around them. The two most primitive examples of this situation are: (1) outdoors, on a spring day when the air is not too hot but the sun is shining. (2) around an open fire, on a cool evening.”

\subsection{Total Thermal Resistance Of TABS}

In Chapter 4 of [35], the 3-dimensional, unsteady heat transfer problem of TABS was approximated to a 1dimensional version under the assumption of $d_{i} / d_{x}>0.3$ and $\delta / d_{x}<0.2$, where $d_{i}[\mathrm{~m}]$ and $\delta[\mathrm{m}]$ are the inner and outer diameters of the water pipes, respectively, and $d_{x}[\mathrm{~m}]$ is the space between two adjacent water pipes.

The total thermal resistance of TABS $R_{t}\left[\mathrm{~m}^{2} \mathrm{~K} / \mathrm{W}\right]$ between the supply-water temperature $T_{S w}\left[\mathrm{~K}\right.$ or $\left.{ }^{\circ} \mathrm{C}\right]$ and the TABS mean core temperature $T_{c}\left[\mathrm{~K}\right.$ or $\left.{ }^{\circ} \mathrm{C}\right]$ was obtained by the series connection of individual thermal resistances:

$$
R_{t}=R_{z}+R_{w}+R_{p}+R_{x}
$$

where $R_{z}$ is the equivalent resistance in the $z$-direction (along the pipe), $R_{w}$ is the resistance caused by convection, $R_{p}$ is the resistance due to the cylindrical pipe wall, and $R_{x}$ is the resistance due to the inserted pipe. A program is written in Matlab to calculate the total thermal resistance of TABS.

\subsection{Applying TABS to the Health Center}

Now let us apply the TABS to the roofs and floor of the health center. The $0.038 \mathrm{~m}$ lightweight concrete of the roof and the $0.102 \mathrm{~m}$ normal-weight concrete slabs of the floor are replaced with the $0.250 \mathrm{~m}$ normal-weight concrete slabs. The water pipes are inserted at the middle of the slabs. The total heat capacity of the roof or floor slabs are $6.64 \times 10^{8} \mathrm{~J} / \mathrm{K}$. The mass of the water in the pipes are about $1221 \mathrm{~kg}$ and thus the heat capacity of the water in the roof or floor is $0.05 \times 10^{8} \mathrm{~J} / \mathrm{K}$, which is much smaller than that of the slabs. The TABS total thermal resistance $R_{t}$ is $0.9191 \mathrm{~m}^{2} \mathrm{~K} / \mathrm{W}$ with the reference surface $1166 \mathrm{~m}^{2}$.

Suppose the supply-water temperature of the TABS is $22^{\circ} \mathrm{C}$, in September the operative temperature of the health center is shown in Figure 9. In the figure, the operative temperature varies between $23.20{ }^{\circ} \mathrm{C}$ and $25.84^{\circ} \mathrm{C}$. Compared to Figure 8, the temperature variation decreases $21.7 \%$ thanks to the large heat capacity of the TABS concrete, and the temperature level drops $1.4^{\circ} \mathrm{C}$ because of the cooling from the TABS. 


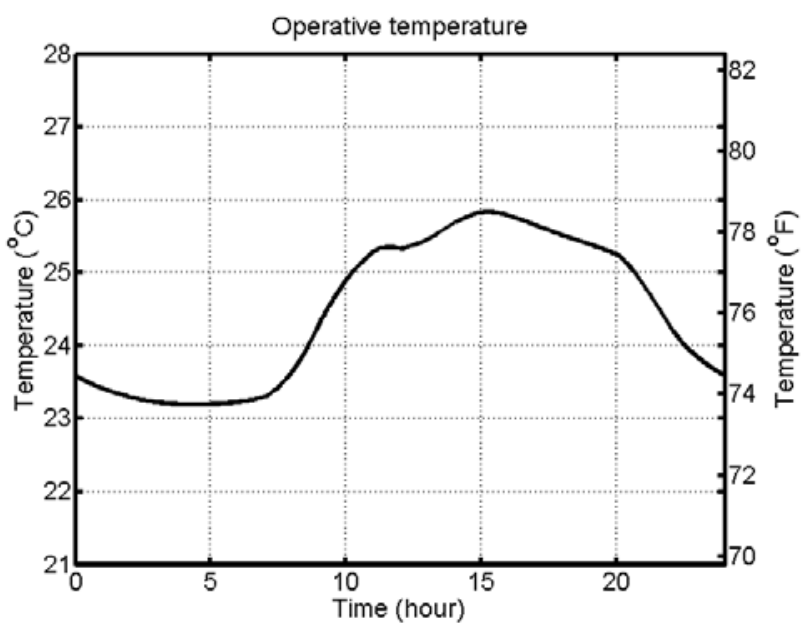

Figure 9. Operative temperature of the health center with TABS in September

In the hottest month July, the average high and low temperatures of the outdoor air are $19{ }^{\circ} \mathrm{C}$ and $28{ }^{\circ} \mathrm{C}$, respectively. In the coldest month January, they are $-5{ }^{\circ} \mathrm{C}$ and $3^{\circ} \mathrm{C}$, respectively. The operative temperatures of the health center with/without TABS in these two months are shown in Figure 10. In July, the TABS supply-water temperature is set to be $18^{\circ} \mathrm{C}$, and in January it is set to be $53{ }^{\circ} \mathrm{C}$. In the figure, the operative temperature variations with TABS are nearly $1{ }^{\circ} \mathrm{C}$ smaller than that without TABS; the operative temperature level without TABS increases about $5{ }^{\circ} \mathrm{C}$ in July and drops nearly $18{ }^{\circ} \mathrm{C}$ in January.

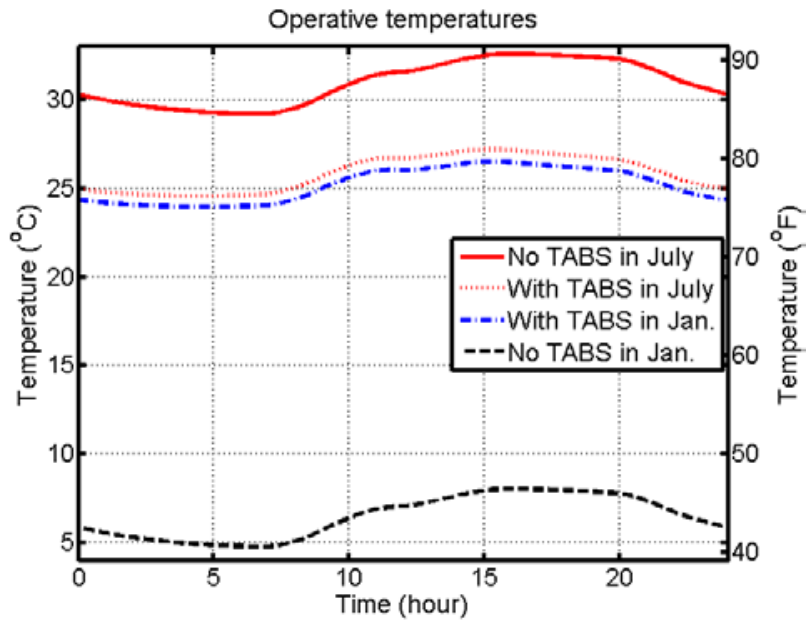

Figure 10. Operative temperatures of the health center with/without TABS in summer/winter

The $18{ }^{\circ} \mathrm{C}$ TABS supply-water temperature for cooling is obviously not low (which is called high-temperature cooling). It is more important to notice that the $53{ }^{\circ} \mathrm{C}$ TABS supply-water temperature for heating actually is very low comparing with conventional heating equipment. This confirms the statement in [23]: "A common misconception is that radiant heating requires high temperature source, or radiant conditioning requires large temperature difference (or gradient). The fact is exactly the opposite..." For conventional heating equipment, the temperature set point is typically about $180^{\circ} \mathrm{F}\left(82^{\circ} \mathrm{C}\right)$. So the TABS heating is one of the so-called low-temperature heating techniques.

The attraction of high-temperature cooling or lowtemperature heating techniques is that we can use low- power equipment driven by natural energy gradient, such as cooling tower and rooftop solar thermal panels. With low-power equipment, the free cooling or heating can be achieved while combining with solar photovoltaics, and thus it can save a great amount of precious electrical power. The possibility of using low-power equipment is not considered here and requires further future study.

\section{Conclusion}

Thermal mass has the ability to absorb and store heat energy during a warm period of heating and to release heat energy during a cool period later. Thermal mass is a powerful tool for controlling building temperatures. In order to investigate the role of exterior and interior thermal mass, a resistor-capacitor model of a small commercial building in the great New York City area is built in Matlab/Simulink. To explore the potential improvement, a TABS, which combines the advantages of radiant cooling and heating with the heat storage of massive building structure, is applied to the building.

After more than 80 case studies under moderate ambient air temperature, we demonstrate that light-weight concrete is a little worse than normal-weight concrete but much better than wood as exterior or interior thermal mass for controlling the building operative temperature variation. In summer or winter when the ambient air temperature is not moderate, extra cooling or heating is necessary and we apply TABS to the building. It concludes that TABS can control both the range and the level of the building operative temperature for thermal comfort. It also shows that with TABS, the building can achieve high-temperature cooling and low-temperature heating. Therefore, we suggest using natural energy gradient driven low-power equipment combining solar photovoltaics in the building to reach free cooling and heating.

\section{References}

[1] Ma, P., Wang, L.-S., "Effective heat capacity of interior planar thermal mass (iPTM) subject to periodic heating and cooling," Energy and Buildings 47. 44-52. Apr.2012.

[2] Schuler, M., in the FORWARD to Thermally Active Surfaces in Architecture by Kiel Moe, Princeton Architectural Press, 2010.

[3] Childs, K.W., Courville, G.E., Bales, E.L., Thermal mass assessment: an explanation of the mechanisms by which building mass influences heating and cooling energy requirement, Oak Ridge National Laboratory, Report No. ORNL/CON-97, US Department of Energy, Oak Ridge, Tennessee, 1983.

[4] Ogoli, D.M., "Predicting indoor temperatures in closed buildings with high thermal mass,” Energy and Buildings 35 (9). 851-862. Oct.2003.

[5] Cheng, V., Ng, E., Givoni, B., "Effect of envelope colour and thermal mass on indoor temperatures in hot humid climate," Solar Energy 78 (4). 528-534. Apr.2005.

[6] Wang, S., Xu, X., "Parameter estimation of internal thermal mass of building dynamic models using genetic algorithm," Energy Conversion and Management 47 (13). 1927-1941. 2006.

[7] Corgnati, S.P., Kindinis, A., "Thermal mass activation by hollow core slab coupled with night ventilation to reduce summer cooling loads,” Building and Environment 42 (9). 3285-3297. Sep.2007.

[8] Henze, G.P., Pfafferott, J., Herkel, S., Felsmann, C., "Impact of adaptive comfort criteria and heat waves on optimal building thermal mass control," Energy and Buildings 39 (2) 221-235. Feb.2007. 
[9] Zhou, J., Zhang, G., Lin, Y., Li, Y., "Coupling of thermal mass and natural ventilation in buildings," Energy and Buildings 40 (6). 979-986. Jun.2008.

[10] Gregory, K., Moghtaderi, B., Sugo, H., Page, A., "Effect of thermal mass on the thermal performance of various Australian residential constructions systems," Energy and Buildings 40 (4). 459-465. Apr.2008.

[11] Krüger, E., Cruz, E.G., Givoni, B., "Effectiveness of indirect evaporative cooling and thermal mass in a hot arid climate," Building and Environment 45 (6). 1422-1433. Jun.2010.

[12] Al-Sanea, S.A., Zedan, M.F., "Improving thermal performance of building walls by optimizing insulation layer distribution and thickness for same thermal mass," Applied Energy 88 (9). 31133124. Sep.2011.

[13] Zhou, J., Zhang, G., Lin, Y., Wang, H., “A new virtual sphere method for estimating the role of thermal mass in natural ventilated buildings,” Energy and Buildings 43 (1). 75-81. Jan.2011.

[14] Dodoo, A., Gustavsson, L., Sathre, R., "Effect of thermal mass on life cycle primary energy balances of a concrete- and a woodframe building,” Applied Energy 92. 462-472. Apr.2012.

[15] Ma, P., Wang, L.-S., "Effective heat capacity of exterior Planar Thermal Mass (ePTM) subject to periodic heating and cooling," Energy and Buildings 47. 394-401. Apr.2012.

[16] Ren, M.J., Wright, J.A., "A ventilated slab thermal storage system model,” Building and Environment 33 (1). 43-52. Jan.1998.

[17] Weber, T., Jóhanneson, G., "An optimized RC-network for thermally activated building components," Building and Environment 40 (1). 1-14. Jan.2005.

[18] Weber, T., Jóhannesson, G., Koschenz, M., Lehmann, B., Baumgartner, T., "Validation of a FEM-program (frequencydomain) and a simplified RC-model (time-domain) for thermally activated building component systems (TABS) using measurement data," Energy and Buildings 37 (7). 707-724. Jul.2005.

[19] Olesen, B.W., de Carli, M., Scarpa, M., Koschenz, M., "Dynamic evaluation of the cooling capacity of thermo-active building systems,” ASHRAE Transactions 112 (1). 350-357. 2006.

[20] Gwerder, M., Lehmann, B., Tötli, J., Dorer, V., Renggli, F., "Control of thermally activated building systems TABS," Applied Energy 85 (7). 565-581. Jul.2008.

[21] Gwerder, M., Tötli, J., Lehmann, B., Dorer, V., Güntensperger, W., Renggli, F., "Control of thermally activated building systems (TABS) in intermittent operation with pulse width modulation," Applied Energy 86 (9). 1606-1616. Sep.2009.

[22] Ma, P., Wang, L.-S., Guo, N., "Modeling of TABS-based thermally manageable buildings in Simulink,” Applied Energy 104. 791-800. Apr.2013.

[23] Wang, L.-S., Ma, P., Hu, E., Giza-Sisson, D., Mueller, G., Guo, N., "A study of building envelope and thermal mass requirements for achieving thermal autonomy in an office building," Energy and Buildings 78. 79-88. Aug.2014.

[24] Široky, J., Oldewurtel, F., Cigler, J., Prívara, S., "Experimental analysis of model predictive control for an energy efficient building heating system,” Applied Energy 88 (9). 3079-3087. Sep.2011.
[25] Ma, P., Wang, L.-S., Guo, N., "Modeling of hydronic radiant cooling of a thermally homeostatic building using a parametric cooling tower," Applied Energy 127. 172-181. Aug.2014.

[26] Wang, L.-S., Thermo-Activic Buildings: Buildings cooled \& heated with natural energies, Stony Brook University research report, 2011.

[27] Heaney, S., Martin, B., Huang, L.-H., Shahus, N., Ma, P., Dey, T., HVAC Project Report-The Suffolk County (Farmingville) Health Center, Stony Brook University, May 2011.

[28] Howell, R.L., Coad, W.J., Sauer, H.J., Jr., Principles of Heating Ventilating and Air Conditioning, 6th ed., ASHRAE, Inc., 2009.

[29] ASHRAE, Inc., 2009 ASHRAE Handbook-Fundamentals, I-P \& S-I ed., 2009.

[30] AMETEK, Inc., Solar energy handbook: theory and applications, 2nd ed., Chilton book company, 1983.

[31] http://www.weather.com/weather/climatology/monthly/usny0485 (Last access on June 6, 2014).

[32] Lehmann, B., Dorer, V., Koschenz, M., "Application range of thermally activated building systems tabs," Energy and Buildings 39 (5). 593-598. May.2007.

[33] Meierhans, R.A., "Slab cooling and earth coupling," ASHRAE Transactions V. 99 (2). 511-518, (DE-93-02-4), 1993.

[34] Meierhans, R.A., "Room air conditioning by means of overnight cooling of the concrete ceiling," ASHRAE Transactions V. 102 (1) 693-697, (AT-96-08-2), 1996.

[35] Koschenz, M., Lehmann, B., Thermoaktive Bauteilsysteme tabs, EMPA, Duebendorf Switzerland, ISBN 3-905594-19-6, 2000 (German only).

[36] Pfafferott, J., Kalz, D., "Thermo-active building systems: Highcomfort, energy-efficient heating and cooling of non-residential buildings," BINE Themeninfo 1, 2007.

[37] Henze, G.P., Felsmann, C., Kalz, D.E., Herkel, S., "Primary energy and comfort performance of ventilation assisted thermoactive building systems in continental climates," Energy and Buildings 40 (2). 99-111. Feb.2008.

[38] Olesen, B.W., "Operation and control of thermally activated building systems (TABS),” REHVA Journal. 24-29. 2011.

[39] Rijksen, D.O., Wisse, C.J., van Schijndel, A.W.M., "Reducing peak requirements for cooling by using thermally activated building systems," Energy and Buildings 42 (3). 298-304. Mar.2010.

[40] Kalz, D.E., Heating and cooling concepts employing environmental energy and thermo-active building systems for lowenergy buildings: system analysis and optimization, Fraunhofer Verlag, Jan.2011.

[41] Ma, P., Thermal Homeostasis in Buildings (THiB): Radiant conditioning of hydronically activated buildings with large fenestration and adequate thermal mass using natural energy for thermal comfort, doctoral thesis, Stony Brook University, May 21, 2013.

[42] Alexander, C., Ishikawa, S., Silverstein, M., Jacobson, M., Fiksdahl-King, I., Angel, S., A Pattern Language: Towns, Buildings, Construction, New York: Oxford University Press, Aug.1977. 